\title{
Antigen-capture ELISA and immunochromatographic test strip to detect the H9N2 subtype avian influenza virus rapidly based on monoclonal antibodies
}

\author{
Yixin Xiao, Fan Yang, Fumin Liu, Hangping Yao, Nanping Wu and Haibo Wu* (1)
}

\begin{abstract}
Background: The H9N2 subtype of avian influenza virus (AIV) has become the most widespread subtype of AIV among birds in Asia, which threatens the poultry industry and human health. Therefore, it is important to establish methods for the rapid diagnosis and continuous surveillance of H9N2 subtype AIV.

Methods: In this study, an antigen-capture enzyme-linked immunosorbent assay (AC-ELISA) and a colloidal gold immunochromatographic test (ICT) strip using monoclonal antibodies (MAbs) 3G4 and 2G7 were established to detect H9N2 subtype Alv.

Results: The AC-ELISA method and ICT strip can detect H9N2 subtype AIV quickly, and do not cross-react with other subtype AIVs or other viruses. The detection limit of AC-ELISA was a hemagglutinin (HA) titer of 4 for H9N2 subtype AIV per $100 \mu \mathrm{l}$ sample, and the limit of detection of the HA protein of AIV H9N2 was $31.5 \mathrm{ng} / \mathrm{ml}$. The ICT strip detection limit was an HA titer of 4 for H9N2 subtype AIV per $100 \mu \mathrm{l}$ sample. Moreover, both detection methods exhibited good reproducibility and repeatability, with coefficients of variation < 5\%. For detection in 200 actual poultry samples, the sensitivities and specificities of AC-ELISA were determined as $93.2 \%$ and $98.1 \%$, respectively. The sensitivities and specificities of the ICT strips were determined as $90.9 \%$ and $97.4 \%$, respectively.
\end{abstract}

Conclusions: The developed AC-ELISA and ICT strips displayed high specificity, sensitivity, and stability, making them suitable for rapid diagnosis and field investigation of H9N2 subtype AIV.

Keywords: H9N2 subtype, Avian influenza virus, AC-ELISA, ICT strip, Sensitivity, Specificity

\section{Introduction}

Influenza A viruses (Orthomyxoviridae family) can infect humans and many other hosts including birds, seals, pigs, cats, horses, and dogs $[1,2]$. According to the antigenic characteristics of the hemagglutinin (HA) and neuraminidase (NA) surface glycoproteins, influenza

\footnotetext{
${ }^{*}$ Correspondence: wuhaibo@zju.edu.cn

State Key Laboratory for Diagnosis and Treatment of Infectious Diseases, and National Clinical Research Center for Infectious Diseases, the First Affiliated Hospital, School of Medicine, Zhejiang University, 79 Qingchun Road, Hangzhou 310003, Zhejiang, China
}

A viruses can be further divided into $18 \mathrm{HA}$ and $11 \mathrm{NA}$ subtypes [3]. Avian influenza viruses (AIVs) are influenza A viruses, which usually circulate in wild aquatic birds [4]. AIV causes a wide range of harm to the host, such that highly pathogenic AIV (HPAIV; H5 and H7) infections of poultry usually result in very high mortality. Low pathogenic AIV (LPAIV) infections can induce mild respiratory symptoms and lead to a reduction in poultry production [5]. Studies have shown that the H9N2 subtype of LPAIV is prone to genetic recombination and exchange gene segments with other AIVs, such as H5N1 
and H7N9 subtype HPAIVs [6, 7]. Currently, H9N2 AIV has become the most common AIV in Asia [8].

Thus, early and rapid detection and prevention of infection with H9N2 AIV is very important. In 1966, the earliest infection with H9N2 AIV was found in domestic poultry in the USA, and since then, outbreaks of H9N2 AIV have occurred worldwide [5, 9]. In China, the earliest H9N2 AIV infection was found in domestic poultry in Guangdong in 1994 [10]. Subsequently a large-scale outbreak occurred in Hebei province in 1998 and spread to most poultry farms across the country [11]. In the poultry industry, infection with H9N2 AIV caused significant economic losses [12]. Moreover, the H9N2 AIV infection rate remains high in poultry, especially in live poultry markets [13]. Studies have demonstrated that the prevalence of H9N2 AIV in poultry markets and farms in Southeast Asian countries is between 3.5 and 25\% [14-19]. Around China, the prevalence of H9N2 AIV is mostly above $10 \%[20,21]$.

Research evidence shows that H9N2 AIV not only infects poultry, but also can infect mammals, including humans [22]. H9N2 AIV infection of humans has been found in certain countries, especially China and Egypt $[23,24]$. Previous studies have indicated the H9N2 AIVs have multiple genotypes and their low pathogenicity in poultry makes these viruses easier to spread $[24,25]$. At the same time, these viruses have been widely present in mammals (such as Chinese pigs). There have been studies showing that the H9N2 AIV can acquire mutations that enhance receptor binding, toxicity, or transmission ability during the replication of mammalian hosts $[22,26]$. Accordingly, some scholars suggested that H9N2 AIV should be considered a potential candidate virus strain for the next pandemic $[25,27]$. Thus, the rapid and precise detection of H9N2 AIV is essential.

There are some laboratory methods that can detect H9N2 AIV, such as virus isolation and quantitative real-time reverse transcription polymerase chain reaction (qRT-PCR) [28]. However, virus isolation is timeconsuming and entails relatively high environmental requirements. The qRT-PCR method has extremely high sensitivity, but requires special equipment and skilled operators [29]. With the development of molecular biology technology, it has become possible to develop relatively convenient and economical detection methods based on monoclonal antibodies (MAbs). The antigen-capture enzyme linked immunosorbent assay (AC-ELISA) and colloidal gold immunochromatographic test (ICT) strip approaches have been established using MAbs [30, 31]. Many viruses can be detected using MAb detection methods, such as rabies virus, human papillomavirus, and human enterovirus [32-34]. In the field of influenza virus detection, AC-ELISA can be developed to evaluate vaccine efficacy and to diagnose infections, and ICT strips have also been used to detect the AIVs, showing good specificity and sensitivity for samples from patients and poultry infected with AIVs [35-37].

The present study aimed to establish AC-ELISA and ICT strip methods using two MAbs to detect H9N2 AIV.

\section{Materials and methods \\ Viruses and cells}

All the viruses used in this study are described in Table 1. All the viruses were obtained from the virus repository in our laboratory $[20,38-41]$. AIVs were stored at $-80^{\circ} \mathrm{C}$ and propagated at $37{ }^{\circ} \mathrm{C}$ using 10-day old chicken embryos, as described previously [20]. Influenza B virus, avian paramyxovirus 4 (APMV-4), infectious bursal disease virus (IBDV), Newcastle disease virus (NDV), and infectious bronchitis virus (IBV) were also acquired from our laboratory virus repository. All viruses were determined using hemagglutinin (HA) and tissue culture infectious dose 50 (TCID50) assays according to standard methods [42]. The experiments involving $\mathrm{H} 5$ and $\mathrm{H} 7$ subtype AIVs were conducted in an accredited Biosafety Level 3 (BSL-3) containment laboratory at the First Affiliated Hospital of Zhejiang University.

Madin-Darby canine kidney (MDCK) cells and SP2/0 mouse myeloma cells were maintained in our laboratory. Purified HA protein from the H9N2 (A/chicken/Zhejiang/329/2011) subtype AIV was purchased from Sino Biological (Beijing, China) [43].

\section{Generation and purification of MAbs}

BALB/c mice (9 weeks old) were immunized with the purified H9N2 subtype AIV HA protein mixed Freund's adjuvant (Sigma, St. Louis, MO, USA) intramuscularly, twice at 3 weeks apart. After 6 weeks, the mice were immunized once more with HA protein by tail vein injection. After 3 days, the spleen lymphocytes of the selected mice were fused with SP2/0 cells [43, 44]. The hybridoma cells were screened using a purified H9N2 HA proteincoated ELISA method. The positive monoclonal hybridoma cell line that was obtained after three consecutive limiting dilutions was continuously subcultured and then injected into mice intraperitoneally. To obtain MAbs, a Protein G column (GE Healthcare, Chicago, IL, USA) was used to purify ascites collected from the mice injected with the hybridoma cells [45].

\section{Isotype and affinity of MAbs}

Isotyping of the MAbs was performed using a Monoclonal Antibody Isotyping Kit (Bio-Rad, Hercules, CA, USA). The affinities of each MAb were measured using ELISA, as described previously [45]. In brief, the ELISA plate was coated with purified H9N2 HA protein $(20 \mathrm{ng} /$ 
Table 1 The specificity and sensitivity of antigen-capture enzyme-linked immunosorbent assay (AC-ELISA) and immunochromatographic test (ICT) strip methods against different viruses

\begin{tabular}{|c|c|c|c|c|c|c|}
\hline \multirow[t]{2}{*}{ Virus } & \multirow[t]{2}{*}{ Subtype } & \multirow{2}{*}{$\begin{array}{l}\text { HA } \\
\text { Titer }\end{array}$} & \multicolumn{2}{|l|}{ AC-ELISA } & \multicolumn{2}{|l|}{ Strip } \\
\hline & & & OD value & $\begin{array}{l}\text { Test limitation (HA } \\
\text { titer) }\end{array}$ & Result & $\begin{array}{l}\text { Test } \\
\text { limitation } \\
\text { (HA titer) }\end{array}$ \\
\hline A/duck /Zhejiang/D4/2018 & $\mathrm{H} 9 \mathrm{~N} 2$ & $2^{6}$ & 1.095 & $2^{2}$ & $+^{\mathrm{a}}$ & $2^{2}$ \\
\hline A/chicken/Zhejiang/1026138/2016 & $\mathrm{H} 9 \mathrm{~N} 2$ & $2^{5}$ & 0.986 & $2^{2}$ & + & $2^{3}$ \\
\hline A/chicken/Zhejiang/13163/2016 & H9N2 & $2^{6}$ & 1.254 & $2^{3}$ & + & $2^{3}$ \\
\hline A/chicken/Zhejiang/221/2016 & $\mathrm{H} 9 \mathrm{~N} 2$ & $2^{7}$ & 1.311 & $2^{2}$ & + & $2^{2}$ \\
\hline A/chicken/Zhejiang/C1/2013 & H9N2 & $2^{7}$ & 1.526 & $2^{2}$ & + & $2^{2}$ \\
\hline A/pigeon/Zhejiang/2P4/2013 & H9N2 & $2^{5}$ & 1.321 & $2^{3}$ & + & $2^{2}$ \\
\hline A/chicken/Zhejiang/4C91/2013 & H9N2 & $2^{5}$ & 1.452 & $2^{3}$ & + & $2^{2}$ \\
\hline A/quail/Zhejiang/D485/2013 & $\mathrm{H} 9 \mathrm{~N} 2$ & $2^{7}$ & 1.421 & $2^{2}$ & + & $2^{2}$ \\
\hline A/chicken/Zhejiang/C7195/2013 & $\mathrm{H} 9 \mathrm{~N} 2$ & $2^{5}$ & 1.321 & $2^{2}$ & + & $2^{2}$ \\
\hline A/chicken/Zhejiang/C497/2013 & $\mathrm{H} 9 \mathrm{~N} 2$ & $2^{7}$ & 1.256 & $2^{2}$ & + & $2^{2}$ \\
\hline A/chicken/Zhejiang/C55/2013 & $\mathrm{H} 9 \mathrm{~N} 2$ & $2^{7}$ & 1.236 & $2^{2}$ & + & $2^{2}$ \\
\hline A/chicken/Zhejiang/329/2011 & $\mathrm{H} 9 \mathrm{~N} 2$ & $2^{7}$ & 1.526 & $2^{2}$ & + & $2^{2}$ \\
\hline A/pigeon/Zhejiang/727044/2014 & $\mathrm{H} 9 \mathrm{~N} 2$ & $2^{5}$ & 1.121 & $2^{3}$ & + & $2^{3}$ \\
\hline A/pigeon/Zhejiang/2P5/2013 & $\mathrm{H} 9 \mathrm{~N} 2$ & $2^{6}$ & 1.336 & $2^{2}$ & + & $2^{3}$ \\
\hline A/quail/Zhejiang/A1/2013 & H9N2 & $2^{5}$ & 1.201 & $2^{2}$ & + & $2^{2}$ \\
\hline A/quail/Zhejiang/A2/2013 & $\mathrm{H} 9 \mathrm{~N} 2$ & $2^{6}$ & 1.233 & $2^{3}$ & + & $2^{3}$ \\
\hline A/quail/Zhejiang/2A6/2013 & H9N2 & $2^{5}$ & 1.115 & $2^{2}$ & + & $2^{2}$ \\
\hline A/egret/Zhejiang/12/2013 & H9N2 & $2^{6}$ & 1.334 & $2^{2}$ & + & $2^{2}$ \\
\hline A/wild duck/Zhejiang/WD5/2014 & H9N2 & $2^{6}$ & 1.256 & $2^{2}$ & + & $2^{3}$ \\
\hline A/duck/Zhejiang/D1/2013 & $\mathrm{H} 1 \mathrm{~N} 2$ & $2^{6}$ & 0.055 & $-{ }^{b}$ & - & - \\
\hline A/chicken/Zhejiang/2CP25/2014 & H1N3 & $2^{5}$ & 0.046 & - & - & - \\
\hline A/duck/Zhejiang/473/2013 & $\mathrm{H} 1 \mathrm{~N} 4$ & $2^{6}$ & 0.078 & - & - & - \\
\hline A/duck/Zhejiang/6D10/2013 & $\mathrm{H} 2 \mathrm{~N} 8$ & $2^{4}$ & 0.069 & - & - & - \\
\hline A/duck/Zhejiang/4613/2013 & $\mathrm{H} 3 \mathrm{~N} 2$ & $2^{6}$ & 0.065 & - & - & - \\
\hline A/duck/Zhejiang/5/2011 & $\mathrm{H} 3 \mathrm{~N} 3$ & $2^{7}$ & 0.028 & - & - & - \\
\hline A/duck/Zhejiang/D1-3/2013 & H3N6 & $2^{6}$ & 0.047 & - & - & - \\
\hline A/duck/Zhejiang/727145/2014 & $\mathrm{H} 4 \mathrm{~N} 2$ & $2^{4}$ & 0.054 & - & - & - \\
\hline A/duck/Zhejiang/409/2013 & H4N6 & $2^{5}$ & 0.054 & - & - & - \\
\hline A/goose/Zhejiang/97/2014 & $\mathrm{H} 5 \mathrm{~N} 1$ & $2^{6}$ & 0.039 & - & - & - \\
\hline A/duck/Zhejiang/6DK19/2013 & $\mathrm{H} 5 \mathrm{~N} 2$ & $2^{7}$ & 0.033 & - & - & - \\
\hline A/duck/Zhejiang/6D2/2013 & H5N6 & $2^{7}$ & 0.024 & - & - & - \\
\hline A/duck/Zhejiang/W24/2013 & H5N8 & $2^{7}$ & 0.027 & - & - & - \\
\hline A/chicken/Zhejiang/1664/2017 & $\mathrm{H} 6 \mathrm{~N} 1$ & $2^{6}$ & 0.065 & - & - & - \\
\hline A/duck/Zhejiang/727038/2014 & $\mathrm{H} 6 \mathrm{~N} 2$ & $2^{4}$ & 0.055 & - & - & - \\
\hline A/chicken/Zhejiang/727018/2014 & H6N6 & $2^{5}$ & 0.032 & - & - & - \\
\hline A/duck/Zhejiang/DK16/2013 & $\mathrm{H} 7 \mathrm{N3}$ & $2^{5}$ & 0.034 & - & - & - \\
\hline A/chicken/Jiangxi/C25/2014 & H7N7 & $2^{7}$ & 0.062 & - & - & - \\
\hline A/chicken/Zhejiang/ZJU01/2013 & H7N9 & $2^{7}$ & 0.035 & - & - & - \\
\hline A/duck/Zhejiang/6D20/2013 & $\mathrm{H} 10 \mathrm{~N} 2$ & $2^{5}$ & 0.041 & - & - & - \\
\hline A/chicken/Zhejiang/8615/2016 & H1ON3 & $2^{6}$ & 0.077 & - & - & - \\
\hline A/chicken/Zhejiang/2CP2/2014 & H10N7 & $2^{6}$ & 0.053 & - & - & - \\
\hline A/chicken/Zhejiang/102622/2016 & H10N8 & $2^{5}$ & 0.026 & - & - & - \\
\hline A/duck/Zhejiang/727D2/2013 & $\mathrm{H} 11 \mathrm{~N} 3$ & $2^{3}$ & 0.045 & - & - & - \\
\hline A/duck/Zhejiang/71750/2013 & H11N7 & $2^{3}$ & 0.035 & - & - & - \\
\hline Infectious bursal disease virus (IBDV) & NF8 & $2^{5}$ & 0.067 & - & - & - \\
\hline Infectious bronchitis virus (IBV) & $\mathrm{H} 120$ & $2^{5}$ & 0.044 & - & - & - \\
\hline Newcastle disease virus (NDV) & La Sota & $2^{5}$ & 0.032 & - & - & - \\
\hline Avian paramyxovirus 4(APMV-4) & $\mathrm{ZJ}-1$ & $2^{5}$ & 0.058 & - & - & - \\
\hline B/Massachusetts/2/2012 & Yamagata & $2^{5}$ & 0.049 & - & - & - \\
\hline
\end{tabular}


Table 1 (continued)

a" +", positive result

b" -", negative result

well) overnight at $4{ }^{\circ} \mathrm{C}$. MAbs were twofold serially diluted, starting at $1 \mathrm{mg} / \mathrm{ml}$, and added to the plate. Incubation was carried out for $1 \mathrm{~h}$ at $37^{\circ} \mathrm{C}$. Then, goat antimouse IgG (Novus, St Charles, MO USA) was diluted 10,000 times and added as the secondary antibody. Incubation was carried out for $30 \mathrm{~min}$ at $37^{\circ} \mathrm{C}$. The color reaction was performed using the $3,3^{\prime}, 5,5^{\prime}$-tetramethylbenzidine (TMB) reagent (KPL, Gaithersburg, MD, USA). After $10 \mathrm{~min}$, the color reaction was stopped using the terminating reagent (KPL). Between each step, phosphate-buffered saline (PBS) with Tween 20 (PBST) was used to wash the plate five times. An ELISA plate reader (Bio-Rad) was read used to read the optical density (OD) at $450 \mathrm{~nm}$, and the antibody's affinity was estimated as the minimum concentration of the MAb required to provide a positive reaction. The variable genes of the heavy or light chains of the MAbs were sequenced by Sino Biological.

\section{Immunofluorescence analysis}

An immunofluorescence assay (IFA) was used to visualize the binding of the MAbs to the virus-infected MDCK cells [46, 47]. After incubation with the virus for $24 \mathrm{~h}$, virus-infected MDCK cells were fixed with paraformaldehyde. Thereafter, the MDCK cells were permeabilized using Triton X-100. Then, MAbs 3G4 or 2 G7 were added and incubated for $1 \mathrm{~h}$ at $37{ }^{\circ} \mathrm{C}$. The goat anti-mouse IgG heavy plus light chain $(\mathrm{H}+\mathrm{L})$-Alexa Fluor (Abcam, Cambridge, UK) was then added. The wells were washed with PBS three times between each step. The results were scored using an EVOS M7000 instrument (Thermo Fisher Scientific, Waltham, MA, USA).

\section{Preparation of H9N2 AC-ELISA}

The procedure for AC-ELISA (Fig. 1) was described previously $[35,48]$. In brief, based on the results of MAb affinity measurements, MAb 3G4 was selected for capture and used to coat a 96-well ELISA plate at $80 \mathrm{ng} /$ well in $100 \mu$ of coating buffer at $4{ }^{\circ} \mathrm{C}$. After $12 \mathrm{~h}, \mathrm{MAb}$ 2G7, which was selected as the detection antibody, was labelled with horseradish peroxidase (HRP; Innoreagents, Huzhou, China). Then, the ELISA plate was washed and blocked with bovine serum albumin (BSA). After washing, samples were added into the ELISA plate and incubated for $1 \mathrm{~h}$ at $37^{\circ} \mathrm{C}$. Then, after washing the plate, 2G7-MAb-HRP $(4 \mu \mathrm{g} / \mathrm{ml})$ was added and incubated for $30 \mathrm{~min}$ at $37^{\circ} \mathrm{C}$. The plate was then washed and TMB solution was added at $100 \mu \mathrm{l} /$ well. After $10 \mathrm{~min}$, the TMB stop solution was added. The OD value $(450 \mathrm{~nm})$ was then detected using an ELISA reader. An OD value greater than 2.1 times that of the negative control was considered to indicate a positive reaction.

\section{ICT strip preparation}

The procedure for using the ICT strip is shown in Fig. 1. The preparation of the colloidal gold solution was described previously [37, 49]. In brief, $0.01 \% \mathrm{HAuCl} 4$ solution was heated to $100{ }^{\circ} \mathrm{C}$, and then a trisodium

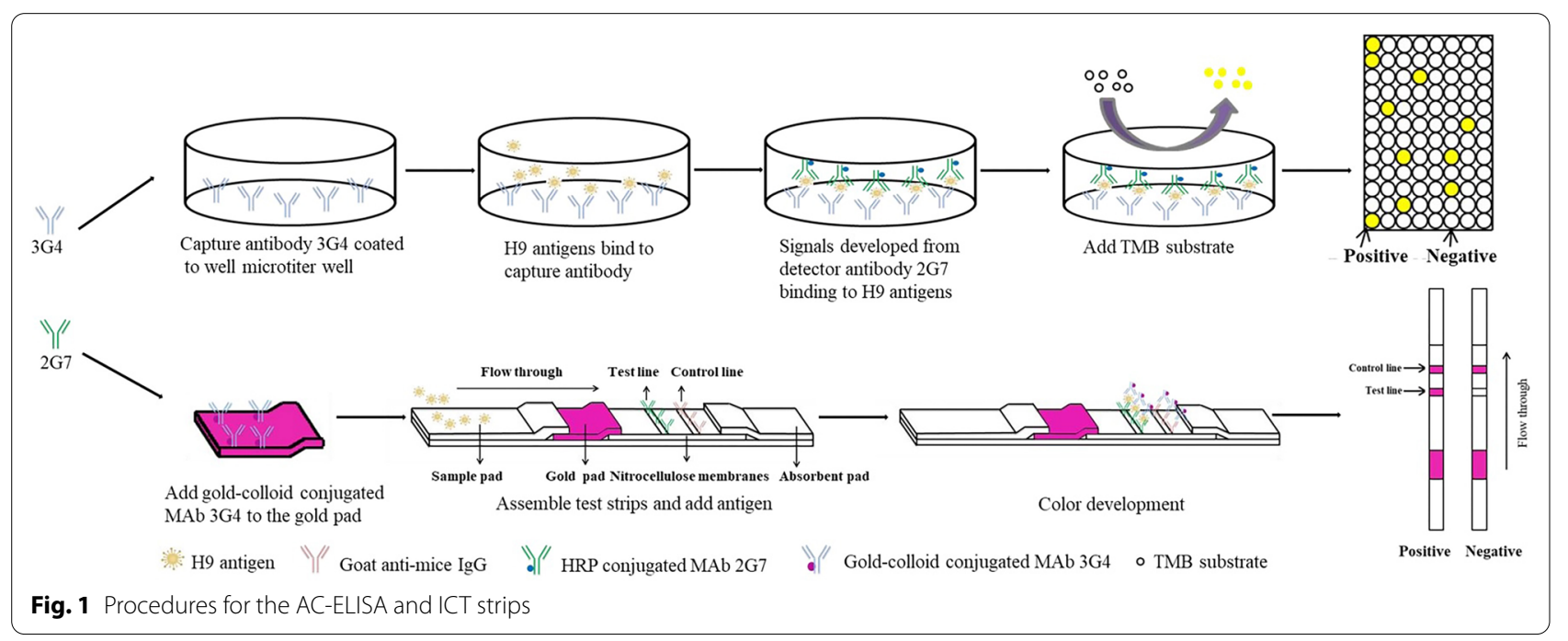


citrate solution was added quickly with continuous vigorous stirring. Then, the colloidal gold solution was continuously boiled until the color changed to wine-red. After cooling, the $\mathrm{pH}$ of the solution was adjusted to 7.2 using potassium carbonate. Then, $10 \mathrm{ml}$ of the colloidal gold solution placed into a glass bottle into which $100 \mu \mathrm{l}$ MAb 3G4 $(1 \mathrm{mg} / \mathrm{ml})$ was added. Incubation was carried out for 30 min with gentle stirring. After blocking with $\mathrm{BSA}$, the solution was centrifuged for $30 \mathrm{~min}$ at $4{ }^{\circ} \mathrm{C}$. The colorless supernatant was discarded and the pellet was re-dissolved with $1 \mathrm{ml}$ PBST (containing 1\% BSA).

The ICT strip contained an absorbent pad, nitrocellulose (NC) membranes, a MAb-gold conjugated, pad and a sample pad. The NC membranes were coated with MAb 2 G7 as the test line and with goat anti-mouse IgG (Solarbio, Beijing, China) as the control line.

\section{Sensitivity, specificity, and repeatability of the H9N2 AC-ELISA and ICT strips}

The specificity of the assays was tested using different subtypes of AIV (19 H9N2 AIVs and 25 other AIV subtypes), and other viruses (IBDV, IBV, APMV-4, NDV, and influenza $B$ virus). To determine the sensitivity, twofold serial dilutions of H9N2 AIV allantoic fluid and purified H9N2 proteins were used. A twofold serial dilution of H10N7 AIV allantoic fluid was used as the negative control. To evaluate repeatability, all samples were tested in triplicate, and all assays were repeated three times.

\section{Assessment of the ability to rapidly detect actual poultry samples}

To assess the clinical application of the two methods, 200 cloacal swabs (100 from chickens and 100 from ducks) collected from 10 poultry farms in Zhejiang Province were detected using multiplex qRT-PCR, AC-ELISA, and ICT strip methods. There were 20 samples for every farm. An Influenza A virus universal PCR kit (Liferiver Bio-Tech, Shanghai, China) was used to perform the qRT-PCR assay [37].

\section{Results}

\section{Isotype and affinity of the MAbs}

Five murine MAbs (3G4, 2G7, 1B12, 1C12, and 2F1) were screened using ELISA. MAbs 3G4, 2G7, 1B12, and 1C12 belonged to the IgG1 subclass, and Mab 2F1 belonged to the IgG2a subclass. Among these MAbs, MAbs 3G4 and 2G7 were chosen to develop the detection method because of their high affinity (Table 2). Although none of the five MAbs displayed hemagglutination inhibition (HI) or virus neutralization (VN) activity against H9N2 subtype AIV, these MAbs reacted with all H9N2 subtype AIVs available in our laboratory (Table 1). Therefore, MAbs 3G4 and 2G7 were complementary to each
Table 2 The characteristics of two monoclonal antibodies (MAbs) used to establish the detection methods

\begin{tabular}{|c|c|c|c|c|c|}
\hline \multirow[t]{2}{*}{ MAbs } & \multicolumn{2}{|l|}{ Isotype $^{a}$} & \multirow[t]{2}{*}{ Affinity $(\mu \mathrm{g} / \mathrm{ml})$} & \multicolumn{2}{|l|}{$\mathrm{CDR}^{\mathrm{b}}$} \\
\hline & subclass & Type & & Heavy chain & Light chain \\
\hline $2 \mathrm{G} 7$ & $\operatorname{lgG1}$ & K & 15.63 & ARLTGTDY & QQGDFIPRT \\
\hline $3 G 4$ & $\lg G 1$ & $\mathrm{~K}$ & 15.63 & ESQRG & WQGTHFPYT \\
\hline
\end{tabular}

${ }^{a}$ The immunoglobulin isotypes of MAbs

${ }^{\mathrm{b}}$ Complementarity-determining region

other and hence likely to be suitable for rapid detection of H9N2 subtype AIVs.

\section{Immunofluorescence analysis}

IFA was used to analyze whether the MAbs could recognize H9N2 subtype AIV in MDCK cells. Neither MAb exhibited non-specific binding to MDCK cells infected with H5N1, H6N1, and H7N3 subtype AIVs; However, MAbs 3G4 and 2G7 showed strong reactivity toward MDCK cells infected with H9N2 subtype AIV (Fig. 2).

\section{Assessment of the AC-ELISA}

To determine its specificity, AC-ELISA was tested using different strains of viruses, including H9N2 subtype AIVs and other virus strains (Table 1 and Fig. 3a). No crossreactivity was observed for any of the other subtypes of influenza A virus $(\mathrm{H} 1, \mathrm{H} 2, \mathrm{H} 3, \mathrm{H} 4, \mathrm{H} 5, \mathrm{H} 6, \mathrm{H} 7, \mathrm{H} 10$, and H11) or for the other viruses tested (NDV, APMV-4, IBV, IBDV, and influenza B virus).

To determine the sensitivity of AC-ELISA, three different H9N2 subtype AIVs were assessed alongside the H10N8 subtype AIV as a negative control. The four selected viruses were twofold serially diluted to determine the detection limit (Table 1 and Fig. 3b). The detection limits were $4 \mathrm{HA}$ titer in $100 \mu \mathrm{l}$ of virus sample (A/chicken/Zhejiang/329/2011, A/quail/Zhejiang/ D485/2011 and A/chicken/Zhejiang/221/2011). The detection limit of AC-ELISA for the H9N2 HA protein was $31.5 \mathrm{ng} / \mathrm{ml}$ (Fig. 3c).

To evaluate repeatability, twofold serially diluted H9N2 subtype AIV was detected (A/chicken/Zhejiang/329/2011). In the intra- and inter-batch repeatability tests, the coefficient of variation $(\mathrm{CV} \%)$ was $<5 \%$ (Table 3 and Table 4), which showed that the AC-ELISA method possessed good reproducibility.

\section{Assessment of the ICT strip assay}

The specificity of the ICT strip was tested using H9N2 viruses and other non-H9N2 viruses, as described above. Only the H9N2 subtype AIV samples showed positive results (Fig. 4a). The result suggested that the ICT strip could specifically detect H9N2 subtype AIVs (Table 1). 


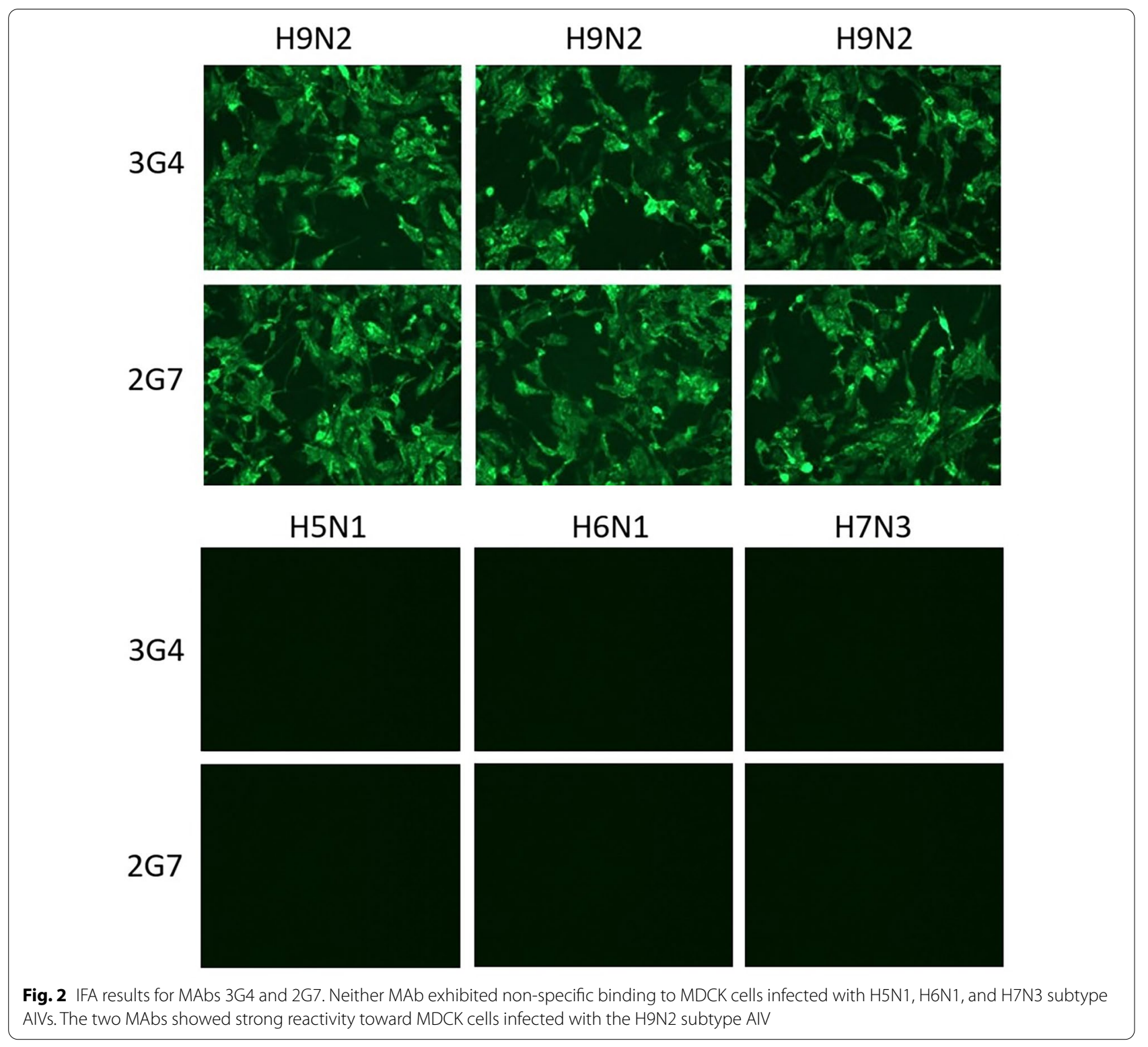

Two-fold serially diluted allantoic fluid from H9N2 subtype AIV (A/chicken/Zhejiang/329/2011)-infected chicken eggs was used to test the sensitivity of the strip. The detection limit of the ICT strip was $100 \mu \mathrm{l}$ of allantoic fluid containing a $4 \mathrm{HA}$ titer of the virus or a median tissue culture infectious dose (TCID50) of $10^{3.15}$ (Fig. 4b).

To verify their stability, the ICT strips were tested after being assembled for 30 and 60 days, and the results revealed comparable specificity and sensitivity to newly assembled ICT strips.

\section{Actual application of AC-ELISA and ICT strip methods}

To assess the actual clinical application of the methods, cloacal swabs were collected from poultry in farms and subjected to analysis by qRT-PCR, AC-ELISA, and ICT strips (Table 5). We used the results of qRT-PCR as the standard, using which, 44 samples were determined to be positive. By comparison, the results of AC-ELISA showed that 41 of the 200 poultry samples were positive, and the ICT strip assay result identified 40 of 200 poultry samples as positive. Furthermore, the positive samples identified by qRT-PCR and AC-ELISA were confirmed to be the same samples. The sensitivity and specificity of the AC-ELISA method were calculated as $93.2 \%$ (41/44) and $98.1 \%(153 / 156)$, respectively. The sensitivity and specificity of the ICT strips were $90.9 \%(40 / 44)$ and 97.4\% (152/156), respectively. These results indicated that both AC-ELISA and ICT strip methods exhibited 

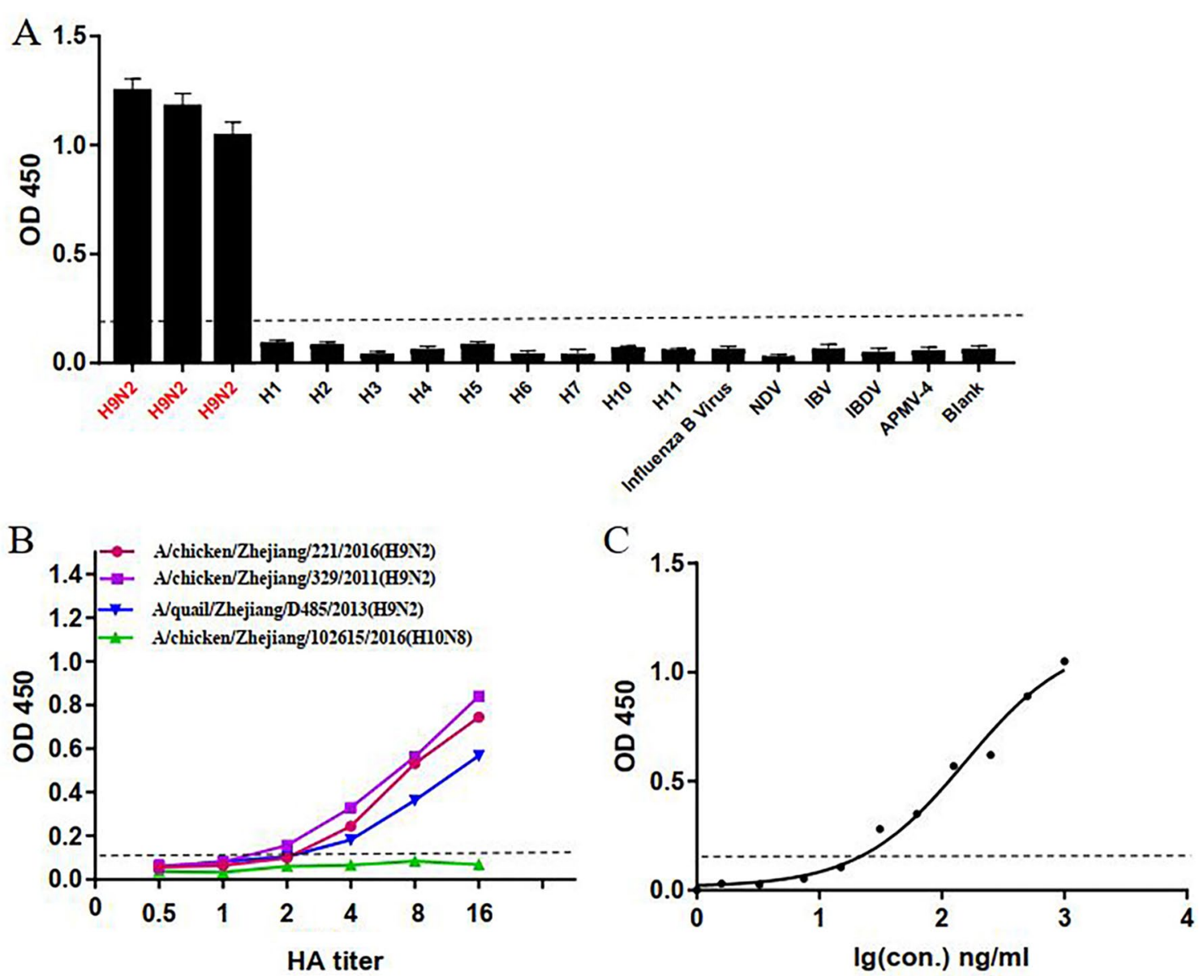

Fig. 3 Assessment of AC-ELISA. a To determine the specificity, samples of $100 \mu$ l of the H9N2 subtype AIVs or non-H9N2 viruses (OD value) allantoic fluid were measured and averaged from three independent tests. b To test the sensitivity, three different H9N2 subtype AlVs and one H10N8 subtype AIV (negative control) at an HA titer of $2^{4}$ were twofold serially diluted. $\mathbf{c}$ Standard curve of AC-ELISA for the purified H9 HA protein (A) chicken/Zhejiang/329/2011). The limit of detection was $31.5 \mathrm{ng} / \mathrm{ml}$. The OD was measured at $450 \mathrm{~nm}$, and the cut-off value is denoted by a dotted line

Table 3 Intra-batch variation in antigen-capture enzyme-linked immunosorbent assay (AC-ELISA) detection of the H9N2 subtype avian influenza virus

\begin{tabular}{llllll}
\hline HA titer & \multicolumn{2}{l}{ OD value in intra-batch } & Mean \pm SD & CV\% \\
\cline { 2 - 4 } & $\mathbf{1}$ & $\mathbf{2}$ & $\mathbf{3}$ & & \\
\hline $2^{5}$ & 1.105 & 1.132 & 1.112 & $1.116 \pm 0.014$ & 1.3 \\
$2^{4}$ & 0.825 & 0.853 & 0.844 & $0.841 \pm 0.014$ & 1.7 \\
$2^{3}$ & 0.552 & 0.564 & 0.572 & $0.563 \pm 0.010$ & 1.8 \\
$2^{2}$ & 0.322 & 0.342 & 0.325 & $0.330 \pm 0.011$ & 3.3 \\
$2^{1}$ & 0.153 & 0.163 & 0.156 & $0.157 \pm 0.005$ & 2.9 \\
$2^{0}$ & 0.082 & 0.078 & 0.082 & $0.081 \pm 0.002$ & 2.9 \\
\hline
\end{tabular}

${ }^{\mathrm{a}} \mathrm{CV} \%$, coefficient of variation
Table 4 Inter-batch variation in antigen-capture enzyme-linked immunosorbent assay (AC-ELISA) detection of the H9N2 subtype avian influenza virus

\begin{tabular}{llllll}
\hline HA titer & \multicolumn{2}{l}{ OD value in inter-batch } & Mean \pm SD & CV\% \\
\cline { 2 - 4 } & $\mathbf{1}$ day & 30 days & $\mathbf{6 0 ~ d a y s}$ & & \\
\hline $2^{5}$ & 1.197 & 1.116 & 1.138 & $1.150 \pm 0.042$ & 3.6 \\
$2^{4}$ & 0.841 & 0.861 & 0.872 & $0.858 \pm 0.016$ & 1.9 \\
$2^{3}$ & 0.563 & 0.565 & 0.535 & $0.554 \pm 0.017$ & 3.0 \\
$2^{2}$ & 0.330 & 0.337 & 0.358 & $0.341 \pm 0.015$ & 4.3 \\
$2^{1}$ & 0.157 & 0.155 & 0.168 & $0.160 \pm 0.007$ & 4.3 \\
$2^{0}$ & 0.081 & 0.082 & 0.077 & $0.080 \pm 0.003$ & 3.4 \\
\hline
\end{tabular}

${ }^{\mathrm{a}} \mathrm{CV} \%$, coefficient of variation 


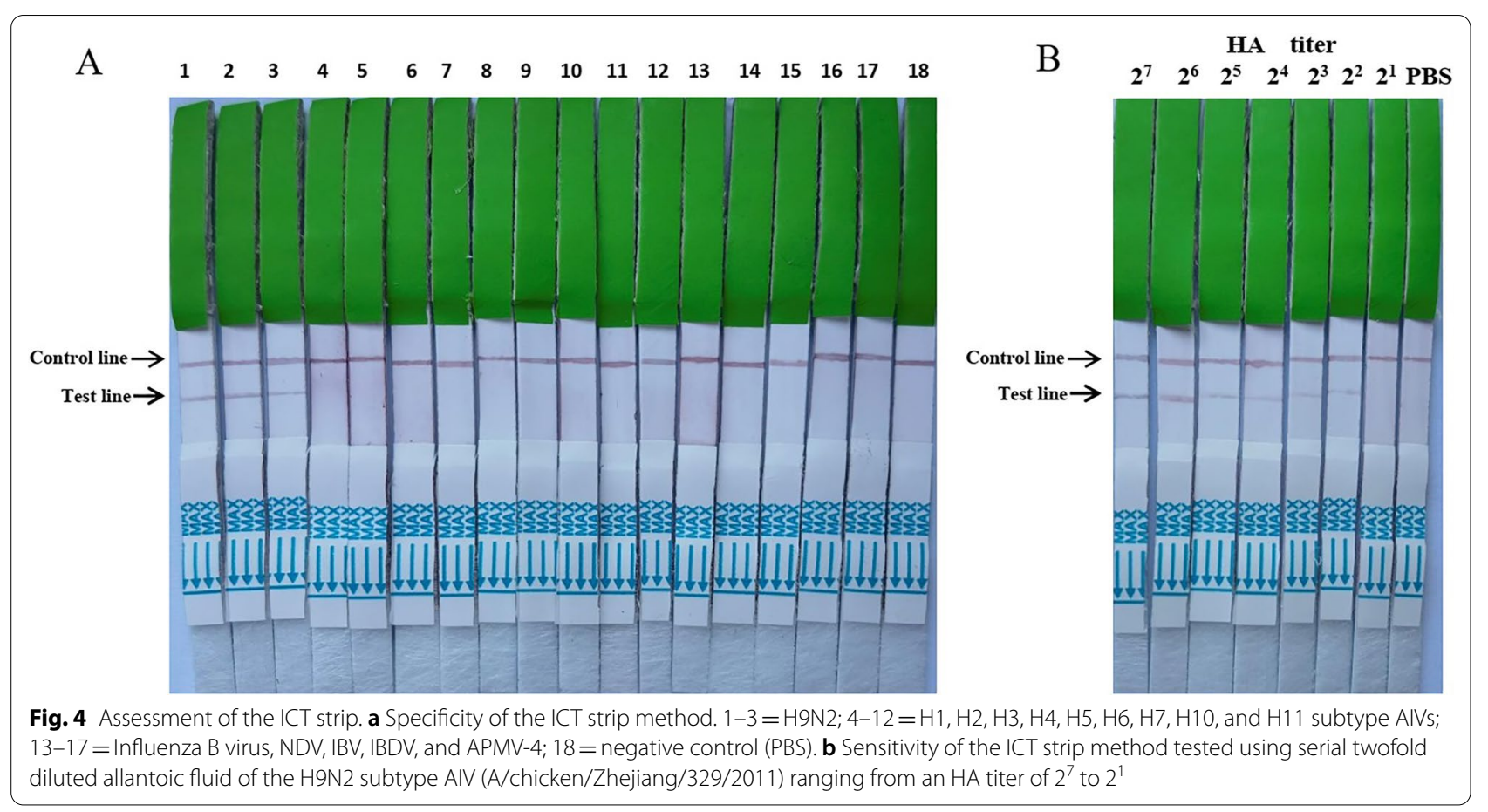

Table 5 The result of detecting poultry samples using AC-ELISA, ICT strip and qRT-PCR methods

\begin{tabular}{lllll}
\hline Number of samples & AC-ELISA & & \multicolumn{2}{l}{ Strip } \\
& Positive & Negative & Positive & \\
\hline qRT-PCR & & & 40 \\
Positive (44) & 41 & 3 & 4 & 4 \\
Negative (156) & 3 & 153 & $90.9 \%(40 / 44)$ \\
Sensitivity & $93.2 \%(41 / 44)$ & & $97.4 \%(152 / 156)$ \\
Specificity & $98.1 \%(153 / 156)$ & & \\
\hline
\end{tabular}

high sensitivity and specificity for environmental sample detection.

\section{Discussion}

Epidemic of H9N2 subtype AIVs have caused direct financial losses to the poultry industry and threatened human health [50]. Since the 1990s, many countries have gradually begun to immunize poultry with specific vaccines [51]. However, epidemiological studies have shown that H9N2 AIV is still ubiquitous in poultry around the world and has become an endemic disease [9]. Furthermore, although infections with the H9N2 AIV only induce mild respiratory symptoms, its causes large losses to the poultry industry [50]. Therefore, the establishment of rapid detection methods for H9N2 AIV will be of great significance in monitoring its infection and spread.

The AC-ELISA and ICT strip methods were developed to rapidly detect the H9N2 AIVs based on suitable
MAbs. MAbs 3G4 and 2G7 were selected because of their high affinity. Although MAbs 3G4 and 2G7 did not show $\mathrm{HI}$ and $\mathrm{VN}$ activities, they reacted specifically with H9 HA antigens. This indicated that the MAbs might bind to a linear epitope on the HA antigen, which meets the diagnostic requirements [44]. Therefore, the MAbs were used to establish the H9N2 subtype detection method employed in the AC-ELISA and ICT strip methods.

An ICT strip to detect one strain of H9N2 virus was developed previously and showed good sensitivity and specificity [44]. However, an AC-ELISA method to detect H9N2 AIV has not been reported. Thus, the developed AC-ELISA method could provide a new option to detect H9N2 AIV rapidly. In this study, the AC-ELISA and ICT strip methods showed good sensitivity, specificity, and repeatability. The detection sensitivity of AC-ELISA and ICT strips were 4 HA titer 
for $100 \mu \mathrm{l}$ samples, and neither showed cross-reactivity with any of the non-H9N2 viruses.

In the detection of actual poultry samples, the ACELISA method achieved slightly higher specificity and sensitivity than the ICT strips [45]. This might be related to the visual identification method used in the ICT strip. However, the ICT strip is more convenient to carry and the results can be displayed within $10 \mathrm{~min}$. Thus it is more suitable for field investigation [52].

\section{Conclusion}

In conclusion, the AC-ELISA and ICT strip methods were established using two MAbs to detect H9N2 subtype AIVs rapidly. The two methods have good specificity and sensitivity, and possessing important application value for the rapid detection of viral diseases, and could be further applied in clinical practice.

\begin{abstract}
Abbreviations
AIV: Avian influenza virus; AC-ELISA: Antigen-capture enzyme-linked immunosorbent assay; ICT: Immunochromatographic test; HA: Hemagglutinin; NA: Neuraminidase; qRT-PCR: Quantitative real-time reverse transcription-polymerase chain reaction; MAb: Monoclonal antibody; NDV: Newcastle disease virus; APMV-4: Avian paramyxovirus-4; IBV: Infectious bronchitis virus; IBDV: Infectious bursal disease virus; MDCK: Madin-Darby canine kidney; BSA: Bovine serum albumin; TMB: Tetramethylbenzidine; HRP: Horseradish peroxidase; PBS: Phosphate buffered saline; PBST: Phosphate buffered saline- $0.1 \%$ Tween 20; $\mathrm{CV}$ : Coefficient of variation.

\section{Acknowledgements}

Not applicable.

\section{Authors' contributions}

Individual contributions to the work are as follows: Conception and study design, $Y X, Y X$; data acquisition and analysis, $F Y, F L$; drafting of the manuscript, $Y X$; translation and editing of the manuscript, $Y X, W H$; and critical revision of the manuscript, $Y X, W H$. All authors read and approved the final manuscript.
\end{abstract}

\section{Funding}

This study was funded by Grants from the National Science and Technology Major Project for the Control and Prevention of Major Infectious Diseases in China (2018ZX10711001, 2018ZX10102001 and 2020ZX10001016-004-002), and Zhejiang Provincial Natural Science Foundation of China (LY19H260006).

\section{Availability of data and materials}

The dataset used and analyzed during the current study is available from the corresponding author upon reasonable request.

\section{Declarations}

Ethics approval and consent to participate

The Animal Ethics Committee of First Affiliated Hospital, School of Medicine, Zhejiang University approved all animal experiment in this study (No. 2017-015).

\section{Consent for publication}

Not applicable.

\section{Competing interests}

The authors declare no conflict of interest.
Received: 27 April 2021 Accepted: 23 September 2021

Published online: 02 October 2021

\section{References}

1. Petrova VN, Russell CA. The evolution of seasonal influenza viruses. Nat Rev Microbiol. 2018;16:47-60.

2. Borkenhagen LK, Salman MD, Ma MJ, Gray GC. Animal influenza virus infections in humans: a commentary. Int J Infect Dis. 2019;88:113-9.

3. Jung YJ, Lee YT, Ngo VL, Cho YH, Ko EJ, Hong SM, et al. Heat-killed Lactobacillus casei confers broad protection against influenza A virus primary infection and develops heterosubtypic immunity against future secondary infection. Sci Rep. 2017;7:17360.

4. Kim SH, Choi JW, Kim AR, Lee SC, Yoon MY. Development of ssDNA aptamers for diagnosis and inhibition of the highly pathogenic avian influenza virus subtype H5N1. Biomolecules. 2020;10:1116.

5. Zhang Y, Wei Y, Liu K, Huang M, Li R, Wang Y, et al. Recombinant influenza H9N2 virus with a substitution of $\mathrm{H} 3$ hemagglutinin transmembrane domain showed enhanced immunogenicity in mice and chicken. Sci Rep. 2017;7:17923.

6. Liu D, Shi W, Shi Y, Wang D, Xiao H, Li W, et al. Origin and diversity of novel avian influenza A H7N9 viruses causing human infection: phylogenetic, structural, and coalescent analyses. Lancet. 2013;381:1926-32.

7. Nagy A, Mettenleiter TC, Abdelwhab EM. A brief summary of the epidemiology and genetic relatedness of avian influenza H9N2 virus in birds and mammals in the Middle East and North Africa. Epidemiol Infect. 2017:145:3320-33.

8. Gu M, Xu L, Wang X, Liu X. Current situation of H9N2 subtype avian influenza in China. Vet Res. 2017;48:49.

9. Alexander DJ. An overview of the epidemiology of avian influenza. Vaccine. 2007;25:5637-44.

10. Arai Y, Kawashita N, Ibrahim MS, Elgendy EM, Daidoji T, Ono T, et al. PB2 mutations arising during H9N2 influenza evolution in the Middle East confer enhanced replication and growth in mammals. PLoS Pathog. 2019;15:e1007919.

11. Liu H, Liu X, Cheng J, Peng D, Jia L, Huang Y. Phylogenetic analysis of the hemagglutinin genes of twenty-six avian influenza viruses of subtype H9N2 isolated from chickens in China during 1996-2001. Avian Dis. 2003;47:116-27.

12. Hajam IA, Senevirathne A, Hewawaduge C, Kim J, Lee JH. Intranasally administered protein coated chitosan nanoparticles encapsulating influenza H9N2 HA2 and M2e mRNA molecules elicit protective immunity against avian influenza viruses in chickens. Vet Res. 2020;51:37.

13. Peacock THP, James J, Sealy JE, Iqbal M. A global perspective on H9N2 avian influenza virus. Viruses. 2019;11:620.

14. Turner JC, Feeroz MM, Hasan MK, Akhtar S, Walker D, Seiler P, et al. Insight into live bird markets of Bangladesh: an overview of the dynamics of transmission of $\mathrm{H} 5 \mathrm{~N} 1$ and $\mathrm{H} 9 \mathrm{~N} 2$ avian influenza viruses. Emerg Microbes Infect. 2017;6:e12.

15. Negovetich NJ, Feeroz MM, Jones-Engel L, Walker D, Alam SM, Hasan K, et al. Live bird markets of Bangladesh: H9N2 viruses and the near absence of highly pathogenic H5N1 influenza. PLoS ONE. 2011;6:e19311.

16. Thuy DM, Peacock TP, Bich VTN, Fabrizio T, Hoang DN, Tho ND, et al. Prevalence and diversity of H9N2 avian influenza in chickens of Northern Vietnam, 2014. Infect Genet Evol. 2016;44:530-40.

17. Ali M, Yaqub T, Mukhtar N, Imran M, Ghafoor A, Shahid MF, et al. Prevalence and phylogenetics of $\mathrm{H} 9 \mathrm{n} 2$ in backyard and commercial poultry in Pakistan. Avian Dis. 2018;62:416-24.

18. Parvin R, Begum JA, Nooruzzaman M, Chowdhury EH, Islam MR, Vahlenkamp TW. Review analysis and impact of co-circulating H5N1 and H9N2 avian influenza viruses in Bangladesh. Epidemiol Infect. 2018;146:1259-66.

19. Chaudhry M, Rashid HB, Angot A, Thrusfield M, Bronsvoort BMD, Capua I, et al. Risk factors for avian influenza H9 infection of chickens in live bird retail stalls of Lahore District, Pakistan 2009-2010. Sci Rep. 2018;8:5634.

20. Wu H, Peng X, Peng X, Cheng L, Lu X, Jin C, et al. Genetic and molecular characterization of H9N2 and H5 avian influenza viruses from live poultry markets in Zhejiang Province, eastern China. Sci Rep. 2015;5:17508. 
21. Chen LJ, Lin XD, Guo WP, Tian JH, Wang W, Ying XH, et al. Diversity and evolution of avian influenza viruses in live poultry markets, free-range poultry and wild wetland birds in China. J Gen Virol. 2016;97:844-54.

22. Xu Q, Xie Z, Xie L, Xie Z, Deng X, Liu J, et al. Characterization of an Avian Influenza Virus H9N2 Strain Isolated from a Wild Bird in Southern China. Genome Announc. 2014;2:e00600.

23. Arai Y, Kawashita N, Elgendy EM, Ibrahim MS, Daidoji T, Ono T, et al. PA Mutations inherited during viral evolution act cooperatively to increase replication of contemporary $\mathrm{H} 5 \mathrm{~N} 1$ influenza virus with an expanded host range. J Virol. 2020;95:e01582.

24. Ma C, Cui S, Sun Y, Zhao J, Zhang D, Zhang L, et al. Avian influenza A (H9N2) virus infections among poultry workers, swine workers, and the general population in Beijing, China, 2013-2016: a serological cohort study. Influenza Other Respir Viruses. 2019;13:415-25.

25. Li C, Yu K, Tian G, Yu D, Liu L, Jing B, et al. Evolution of H9N2 influenza viruses from domestic poultry in Mainland China. Virology. 2005;340:70-83.

26. Li X, Shi J, Guo J, Deng G, Zhang Q, Wang J, et al. Genetics, receptor binding property, and transmissibility in mammals of naturally isolated H9N2 Avian Influenza viruses. PLoS Pathog. 2014;10:e1004508.

27. Bhatta TR, Chamings A, Vibin J, Klaassen M, Alexandersen S. Detection of a reassortant $\mathrm{H} 9 \mathrm{~N} 2$ avian influenza virus with intercontinental gene segments in a resident Australian chestnut teal. Viruses. 2020;12:88.

28. Killian ML, Zhang Y, Panigrahy B, Trampel D, Yoon KJ. Identification and characterization of $\mathrm{H} 2 \mathrm{~N} 3$ avian influenza virus from backyard poultry and comparison with novel H2N3 swine influenza virus. Avian Dis. 2011:55:611-9.

29. Kandie R, Ochola R, Njaanake K. Evaluation of fluorescent in-situ hybridization technique for diagnosis of malaria in Ahero Sub-County hospital. Kenya BMC Infect Dis. 2018;18:22.

30. Moreno A, Lelli D, Lavazza A, Sozzi E, Zanni I, Chiapponi C, et al. MAbbased competitive ELISA for the detection of antibodies against influenza D virus. Transbound Emerg Dis. 2019;66:268-76.

31. Li W, Liu L, Chen L, Shang S. Evaluation of a commercial colloidal gold assay for detection of influenza $A$ and $B$ virus in children's respiratory specimens. Fetal Pediatr Pathol. 2020;39:93-8.

32. Kiener TK, Lim XF, Jia Q, Meng T, Chow VT, Kwang J. Characterization of a monoclonal antibody against the 3D polymerase of enterovirus 71 and its use for the detection of human enterovirus A infection. J Virol Methods. 2012;180:75-83.

33. Wang L, Hu YC, Xiao CY, Wang F, Liu YF, Tang LH, et al. Comparative testing of HPV L1 protein monoclonal antibody panel for the detection of HPV in cervical exfoliated cells. J Virol Methods. 2018;257:33-41.

34. Zhao W, Su J, Zhao N, Liu J, Su S. Development of monoclonal antibodies for detection of conserved and variable epitopes of large protein of rabies virus. Viruses. 2021;13:220.

35. Shim DH, Kim MJ, Cha HR, Park ES, Kim AR, Park JH, et al. Development of a HA1-specific enzyme-linked immunosorbent assay against pandemic influenza virus A H1N1. Clin Exp Vaccine Res. 2019;8:70-6.

36. Sun Z, Shi B, Meng F, Ma R, Hu Q, Qin T, et al. Development of a colloidal gold-based immunochromatographic strip for rapid detection of H7N9 influenza viruses. Front Microbiol. 2018;9:2069.

37. Jin C, Wu N, Peng X, Yao H, Lu X, Chen Y, et al. Comparison of a new gold immunochromatographic assay for the rapid diagnosis of the novel influenza A (H7N9) virus with cell culture and a real-time reverse-transcription PCR assay. Biomed Res Int. 2014;2014:425051.
38. Wu H, Guo C, Lu R, Xu L, Wo E, You J, et al. Characterization of a highly pathogenic H5N1 avian influenza virus isolated from ducks in Eastern China in 2011. Arch Virol. 2012;157:1131-6.

39. Wu H, Peng X, Peng X, Cheng L, Wu N. Molecular characterization of novel reassortant $\mathrm{H} 6 \mathrm{~N} 2$ subtype avian influenza viruses isolated from poultry in Eastern China, in 2014. Infect Genet Evol. 2015;36:41-5.

40. Wu H, Lu R, Peng X, Liu F, Cheng L, Wu N. Characterization of reassortant H1-subtype avian influenza viruses isolated from poultry in Zhejiang Province in China from 2013 to 2015. Arch Virol. 2017;162:3493-500.

41. Wu H, Lu R, Peng X, Peng X, Cheng L, Liu F, et al. Characterization of novel reassortant influenza $A(H 5 N 2)$ viruses isolated from poultry in Eastern China, 2015. Front Microbiol. 2017:8:741.

42. Peng $X$, Liu F, Wu H, Peng $X, X u Y$, Wang $L$, et al. Amino acid substitutions HA A150V, PA A343T, and PB2 E627K increase the virulence of H5N6 influenza virus in mice. Front Microbiol. 2018;9:453.

43. Shen C, Chen J, Li R, Zhang M, Wang G, Stegalkina S, et al. A multimechanistic antibody targeting the receptor binding site potently cross-protects against influenza B viruses. Sci Transl Med. 2017;9:eaam5752.

44. He Q, Velumani S, Du Q, Lim CW, Ng FK, Donis R, et al. Detection of H5 avian influenza viruses by antigen-capture enzyme-linked immunosorbent assay using $\mathrm{H} 5$-specific monoclonal antibody. Clin Vaccine Immunol. 2007;14:617-23.

45. Yang F, Xiao Y, Xu L, Liu F, Yao H, Wu N, et al. Development of an antigencapture enzyme-linked immunosorbent assay and immunochromatographic strip based on monoclonal antibodies for detection of $\mathrm{H} 6$ avian influenza viruses. Arch Virol. 2020;165:1129-39.

46. Liu X, Feng X, Tang Q, Wang Z, Qiu Z, Li Y, et al. Characterization and potential diagnostic application of monoclonal antibodies specific to rabies virus. J Biomed Res. 2010;24:395-403.

47. Nogales A, Piepenbrink MS, Wang J, Ortega S, Basu M, Fucile CF, et al. A highly potent and broadly neutralizing $\mathrm{H} 1$ influenza-specific human monoclonal antibody. Sci Rep. 2018;8:4374.

48. Chen L, Ruan F, Liu M, Zhou J, Song W, Qin K. A sandwich ELISA for detecting the hemagglutinin of avian influenza A (H10N8) virus. J Med Virol. 2019;91:877-80.

49. Niu Y, Wang D, Cui L, Wang B, Pang X, Yu P. Monoclonal antibody-based colloid gold immunochromatographic strip for the rapid detection of tomato zonate spot tospovirus. Virol J. 2018;15:15.

50. Li X, Qu B, He G, Cardona CJ, Song Y, Xing Z. Critical role of HAX-1 in promoting avian influenza virus replication in lung epithelial cells. Mediators Inflamm. 2018;2018:3586132.

51. Castellan DM, Hinrichs J, Fusheng G, Sawitri E, do Dung H, Martin V, et al. Development and application of a vaccination planning tool for avian influenza. Avian Dis. 2014;58:437-52

52. Guswanto A, Allamanda P, Mariamah ES, Munkjargal T, Tuvshintulga $\mathrm{B}$, Takemae $\mathrm{H}$, et al. Evaluation of immunochromatographic test (ICT) strips for the serological detection of Babesia bovis and Babesia bigemina infection in cattle from Western Java. Indonesia Vet Parasitol. 2017:239:76-9.

\section{Publisher's Note}

Springer Nature remains neutral with regard to jurisdictional claims in published maps and institutional affiliations.

Ready to submit your research? Choose BMC and benefit from

- fast, convenient online submission

- thorough peer review by experienced researchers in your field

- rapid publication on acceptance

- support for research data, including large and complex data types

- gold Open Access which fosters wider collaboration and increased citations

- maximum visibility for your research: over 100M website views per year

At $\mathrm{BMC}$, research is always in progress.

Learn more biomedcentral.com/submissions 